DOI https://doi.org/10.30525/978-9934-26-113-8-45

\title{
СТАВЛЕННЯ МЕДИЧНИХ ПРАЦІВНИКІВ ОХОРОНИ ЗДОРОВ'Я ПСИХІАТРИЧНОГО ПРОФІЛЮ УКРАЇНИ ДО ВЛАСНОГО ЗДОРОВ'Я
}

\author{
Чорна В. В.
}

кандидат медичних наук,

доцент кафедри медиџини катастроф та військової медицини Вінницький національний медичний університет імені М. I. Пирогова

\author{
Хлєстова С. С. \\ кандидат педагогічних наук, \\ дочент кафедри медичної біології
}

Вінницький національний медичний університет імені М. I. Пирогова

\section{Гуменюк Н. I.}

старший викладач кафедри медицини катастроф та військової медицини

Вінницький національний медичний університет імені М. І. Пирогова

\section{Поляруш В. В.}

старший викладач кафедри медиџини катастроф та військової медицини Вінницький національний медичний університет імені М. І. Пирогова

\section{Сидорчук Т. М.}

викладач кафедри медицини катастроф та військової медицини Вінницький національний медичний університет імені М. І. Пирогова м. Вінниця, Україна

Видатний український хірург Амосов М. зазначав, що: «...у більшості хвороб винна не природа, не суспільство, а сама людина. Найчастіше вона хворіє через лінощі й жадобу, а інколи - й від нерозмінності» [1]. Українськими вченими Бердник О.В., Добрянскою О.В. та іншими здоров'я населення розглядається як критеріальна характеристика його якості. Носієм людського потенціалу держави $є$ населення і на тлі депопуляційних процесів, постійного зниження чисельності населення 
формування належного рівня людського ресурсу можливе за умови забезпечення високої «якості населення». У рамках системи громадського здоров'я доцільним є проведення динамічного спостереження, аналізу та оцінки стану здоров'я різних контингентів населення, а особливо медичних працівників 3 паралельним динамічним контролем над умовами їхньої життєдіяльності [2].

Збереження психічного, душевного та морального здоров'я у сучасному світі при зростанні психоемоційного навантаження, інформаційного впливу, стресів, є одним із складних процесів в житті медичного працівника охорони здоров'я. Предиктори появи та перебігу змін у психічному і соматичному здоров’ї залежать від емоційного, когнітивного, поведінкового, ціннісно-морального компоненту людинимедика. Збереження власного здоров'я, а особливо медичного персоналу, які працюють в екстремальних умовах, в першу чергу залежить від відповідального ставлення самого медичного працівника охорони здоров'я до себе. Вчені Березовська Р.А, Бехтєрев В.М., Дерябко С.Д., Максименко С.Д., Мясищев В.М., Рубінштейн С.Л., Ясвіна В.А. і багато інших досліджували «ставлення до здоров’я» [3].

У зв'язку з великим навантаженням, відповідальністю та поряд 3 низькою оплатою за роботу медичні працівники втрачають інтерес до життя, до сім’і, задоволеність від роботи. Так, наприклад, при опитуванні лікарів у Шанхаї (Китай) у 64,8\% випадків лікарі були незадоволені роботою, що призводило до конфліктів як на роботі, так і у сім’і $[4,5]$. Під час трудової діяльності у медичних працівників з'являються ознаки тривожного та депресивного реагування, предиктори розвитку емоційного вигорання, втома [6]. Часто як вихід із ситуації медичні працівники шукають вирішення цих проблем шляхом вживання алкоголю та наркотиків, тютюнопаління та задоволення від азартних ігор, думки про намір залишити професію [7].

Отже, психічне, емоційне, душевне здоров’я медичних працівників охорони здоров'я та ознаки його депресивного реагування - взаємопов'язані. В Національних службах охорони здоров'я багатьох країнах світу здоров'я медичних працівників викликає занепокоєння та постійний моніторинг в напрямку покращення умов, мотивації, задоволеності. В країнах СС постійно проводяться опитування, тестування для виявлення зрушень у психічному та соматичному здоров'ї медичних працівників, профілактичні заходи. Постійний моніторинг в Свропейських країнах щодо психічного, соматичного здоров'я медичних працівників спонукало нас провести опитування серед медичних 
працівників психіатричної лікарні щодо оцінки їх відношення до власного здоров'я.

В дослідженні взяли участь 223 медичні працівники Комунального некомерційного підприємства «Вінницька обласна клінічна психоневрологічна лікарня ім. акад. О.І. Ющенка Вінницької обласної Ради»: із них жінок - 189 осіб $(84,7 \%)$, та чоловіків - $34(15,3 \%)$, з яких чоловіків-лікарі - було 25 та 62 лікарів-жінок, середній медичний персонал психіатричних відділень складав 136 осіб, 3 них чоловіків СМП - 9 осіб та жінок СМП - 127.

Середній вік респондентів - медичних працівників склав $41,6 \pm 2,8$ роки. Стаж роботи за професійною діяльністю склав $17,9 \pm 3,4$ роки. В нашому дослідженні використано опитувальник «Ставлення до здоров'я» Березовської Р.А. [8].

Перше місце в ієрархії ціннісно-мотиваційного компоненту в житті медичних працівників психіатричного профілю за результатами дослідження встановлено «щасливе родинне життя». Із загальної кількості респондентів лікарі-психіатри/середній медичний персонал (СМП) чоловіки склали $15,1 \% / 16,3 \%$, лікарі-психіатри і СМП (жінки) 15,6\%/15,9\% відповідно. На другому місці в ієрархії цінностей «особисте здоров'я» лікарі-психіатри/СМП (чоловіки) склали 14,8/15,2\%, лікаріпсихіатри і СМП (жінки) 15,1/15,1\% відповідно. На третьому місці в ієрархії цінностей «незалежність, свобода» в професійній діяльності лікарі-психіатри/СМП (чоловіки) склали 15,0/14,6\%, лікарі-психіатри і СМП (жінки) 14,4/14,3\% відповідно ( $<0,05)$.

Із проведеного дослідження встановлено головні чинники які впливають на здоров'я медичних працівників психіатричного профілю. Серед лікарів чоловіків/жінок головний чинник, який має вплив на здоров'я є «спосіб життя» 15,4/16,0\%, при цьому серед СМП чоловіків/жінок є «збалансоване харчування» 15,2/15,1\% відповідно.

Для зміцнення здоров'я медичні працівники психіатричної лікарні приділяють увагу фізично-оздоровчим вправам. Із загальної кількості респондентів найбільш займаються спортом СМП (чоловіки) і найменш СМП (жінки) - 13,3\%/9,8\% відповідно. В порівняні з гендерними особливостями чоловіки приділяють більше уваги загартовуванню свого організму так, у лікарів/СМП чоловіків і лікарів/СМП жінок наступні данні 9,8/8,9\% і 7,1/7,0\% відповідно.

Щодо ставлення до власного здоров'я медичні працівники психіатричного профілю при погіршені їхнього здоров'я (хвороби) лікаріпсихіатри чоловіки та жінки $35,5 / 35,6 \%$ відповідно займаються самолікуванням, а у 25,8\% випадках лікарі-психіатри (жінки) та у 23,1\% 
випадках СМП (чоловіки) взагалі не звертають увагу на хворобу, що може стати ризиком у розвитку різних професійних захворювань та їх хронізації.

Висновки та подальші перспективи. Ефективності у зазначеній проблемі набудуть:

1. Створення в Україні єдиної електронної системи обміну медичною інформацією щодо стану здоров'я кожного медичного працівника та забезпечення достовірної статистичної звітності, що відповідає вимогам реформування системи охорони здоров’я в Свропейських країнах.

2. Потребує запровадити обов'язкове медичне страхування та забезпечити соціальним пакетом медичних працівників закладів охорони здоров'я, як у Свропейських країн.

3. Запровадження комплексної психогігієнічної роботи з формуванням індивідуальних та соціальних уявлень медичних працівників про своє здоров'я шляхом проведення тренінгів, лекцій, конференцій тощо.

\section{Література:}

1. Амосов Н.М. Энциклопедия Амосова. Алгоритм здоровья: АCT, Сталкер; Москва, Донецк; 2002. 469 с. ISBN 5-17-013203-4, 966596-801-7

2. Здоровье населения как критериальная характеристика его качества. Бердник О.В., Добрянская О.В., Рудницкая О.П., Скочко Т.П. Довкілля $і$ здоров'я. 2018. №1. С.4-8.

3. Бойчук Ю.Д. Загальна теорія здоров'я i здоров'язбереження: колективна монографія. Харьків. 2017. 488c.

4. Jianl F., Zhou H. \& Tang Y. Psychiatry Residents in China: SocioDemographic Characteristics, Career Satisfaction, and Related Factors. Front Psychiatry. 2019.Vol.10: P.177. doi: https://doi.org/10.3389/fpsyt. 2019.00177.eCollection2019

5. Liu J., Yu W. \& Zhang L. Cross-sectional survey on job satisfaction and its associated factors among doctors in tertiary public hospital in Shanghai, China. BMJ Open. 2019. Vol. 9 (3): e023823. doi: https://doi.org/10.1136/ bmjopen-2018-023823

6. Chorna V.V., Makhniuk V.M. \& Khliestova S. Burnout in mental health professionals and the measures to prevent it. Georgian medical al news. 2021. Vol. 1 (310) P.113-118

7. Gerada C. (2017), Doctors and mental health. Jccup Med (Lond). Vol. 30; no. 67 (9), P. 660-661. doi: https://doi.org/10.1093/occmed/kqx090

8. Никифорова Г.С. Практикум по психологии здоровья /за ред. Г.С. Никифорова. СПб.:Питер. 2005. 351 с. 